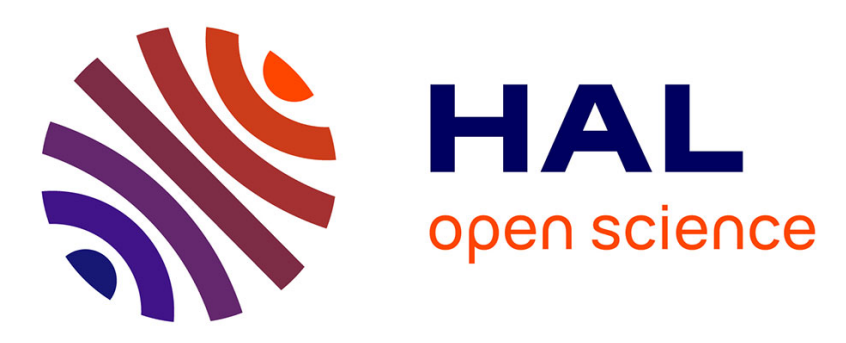

\title{
PEM fuel cell fault detection and identification using differential method: simulation and experimental validation
}

E. Frappé, A. de Bernardinis, O. Bethoux, D. Candusso, F. Harel, C. Marchand, G. Coquery

\section{To cite this version:}

E. Frappé, A. de Bernardinis, O. Bethoux, D. Candusso, F. Harel, et al.. PEM fuel cell fault detection and identification using differential method: simulation and experimental validation. European Physical Journal: Applied Physics, 2011, 54 (2), 10.1051/epjap/2011100277 . hal-00698838

\section{HAL Id: hal-00698838 https://hal.science/hal-00698838}

Submitted on 18 May 2012

HAL is a multi-disciplinary open access archive for the deposit and dissemination of scientific research documents, whether they are published or not. The documents may come from teaching and research institutions in France or abroad, or from public or private research centers.
L'archive ouverte pluridisciplinaire HAL, est destinée au dépôt et à la diffusion de documents scientifiques de niveau recherche, publiés ou non, émanant des établissements d'enseignement et de recherche français ou étrangers, des laboratoires publics ou privés. 


\title{
PEM fuel cell fault detection and identification using differential method: simulation and experimental validation
}

\author{
Emmanuel Frappé ${ }^{1}$, Alexandre De Bernardinis ${ }^{1}$, Olivier Bethoux ${ }^{2}$, Denis Candusso ${ }^{3}$, \\ Fabien Harel $^{3}$, Claude Marchand $^{2}$, and Gérard Coquery ${ }^{1}$ \\ ${ }^{1}$ IFSTTAR LTN / SPEE Labs, 25, allée des Marronniers - Satory, FR- 78000 Versailles, France \\ emmanuel.frappe@ifsttar.fr, alexandre.de-bernardinis@ifsttar.fr \\ ${ }^{2}$ LGEP CNRS UMR 8507 / SPEE Labs, 11, rue Joliot Curie, Plateau du Moulon, FR- 91192 Gif sur Yvette, France \\ olivier.bethoux@1gep.supelec.fr \\ ${ }^{3}$ FC LAB / IFSTTAR, Rue E. Thierry-Mieg, Technopôle - FR- 90010 Belfort, France
}

Keywords: PEMFC, Fault detection, Cell on-line monitoring, Non-intrusive techniques, Flooding.

\begin{abstract}
PEM fuel cell performance and lifetime strongly depend on the polymer membrane and MEA hydration. As the internal moisture is very sensitive to the operating conditions (temperature, stoichiometry, load current, water management...), keeping the optimal working point is complex and requires real time monitoring. This article is centered in the PEM fuel cell stack health diagnosis and more precisely on stack fault detection monitoring. This paper intends to define new, simple and effective methods to get relevant information on usual faults or malfunctions occurring in the fuel cell stack. For this purpose, the authors present a fault detection method using simple and non-intrusive on-line technique based on the space signature of the cell voltages. The authors have the objective to minimize the number of embedded sensors and instrumentation in order to get a precise, reliable and economic solution in a mass market application. A very low number of sensors are indeed needed for this monitoring and the associated algorithm can be implemented on-line. This technique is validated on a 20-cell PEMFC stack. It demonstrates that the developed method is particularly efficient in flooding case. As a matter of fact, it uses directly the stack as a sensor which enables to get a quick feedback on its state of health.
\end{abstract}

\section{Introduction}

Environmental issues have increased the demand for less polluting energy generation technologies. A hydrogen fuel cell (FC) directly converts the electrochemical energy of hydrogen into electricity and only produces heat and water. Proton
Exchange Membrane Fuel Cell (PEMFC) is an attractive technology because of its high power density, its solid membrane and its low operating temperature allowing fast startups and immediate response to changes in the demand of power [1]. However, the membrane has to be fully water saturated in order to enhance its ionic conductivity. As present cells operate at a rated temperature range between $60^{\circ} \mathrm{C}$ to $80^{\circ} \mathrm{C}$, stack water management is a PEMFC key issue. Flooding, due to an excess of water in the cells, inhibits gas transport to the reaction sites and reduces the active surface area of the catalysts. The adverse effect is a significant rise of the activation and concentration losses leading sometimes to a catastrophic decrease of the cell efficiency [2]. On the contrary, a drying situation results in an increase of the membrane resistivity also reducing cell efficiency [3-5]. A long operation with low water content reduces the FC lifetime [6].

Any fault induces a voltage drop [5]. Hence, cell voltage is a good failure indicator, easy to implement. Moreover a voltage sensor is a high bandwidth and accurate device. Nevertheless voltage monitoring makes fault identification difficult to achieve. A first approach is to use the frequency signature of each failure: dehydration adversely affects the ionic conductivity which is a low time response phenomenon, whereas flooding negatively diminishes gas diffusion performance which is a very low time response observable fact. Hence, electrochemical impedance spectroscopy (EIS) provides more complete information about the FC state of health thanks to fuel cell impedance measure [12-14]. However, EIS is a relatively slow method since it needs time to perform a full frequency spectrum [7]. EIS also requires a stabilized working point which is difficult to obtain in real operation. Furthermore, it involves expensive and sometimes voluminous devices to perform the identification. Nevertheless, partial frequency impedance may be fast 
executed and gives interesting but limited information. Hinaje et al. [8] use the HF current ripple generated by the power converter, which is commonly used for FC system electric power conditioning. Using this principle, they perform a membrane resistance measure. Subsequently drying is easily detected by resistance increase but flooding cannot be identified. Even though EIS remains a promising "perturb and observe" technique, it becomes difficult to implement in stack with large number of cells. As a matter of fact, individual cell voltages must be monitored within a stack since a failure (flooding, drying, poisoning,...) can only occur in a few cells. Although some methods exist $[9,10]$, the use of a huge number of sensors is subject to failure. This makes voltage monitoring a challenge for high voltage stacks (long stacks).

Power fuel cells (FCs) are currently developed for applications like traction for electrical vehicle, auxiliary power units (APU) or even battery charger in some high power vehicles or fuel cell hybrid electric vehicles (FCHEVs). For example, the French research project SPACT-80 designed, manufactured and tested in real conditions a robust and durable air/ $\mathrm{H}_{2} \quad 80 \mathrm{~kW}$ PEM fuel cell-based system, specifically developed for railway and road applications [1113]. The GENEPAC project was run in order to design and build a fuel cell for automotive applications. It focuses on the development of a compact $80 \mathrm{~kW}$ fuel cell stack with high output dynamic performances [14]. Recently, Toyota revealed its new FCHV powered by an $80 \mathrm{~kW}$ fuel cell [15]. All these high power PEM stacks are made of large specific areas and composed of about a hundred cells. They are sometimes used as a twin-stack or a multi-stack fuel cell generator [16] because PEMFC power increase is limited by technical and mechanical constraints [17]. As a matter of fact, stacks with large membrane electrode assembly (MEA) and an important cell number are difficult to operate because of heterogeneous fluidic distribution between cells. This discrepancy affects FC performances [18] and makes water management difficult to operate efficiently. Consequently online monitoring is particularly important for safe operating. In order to get a precise, reliable and economic solution in a mass market application, the objective is to minimize the number of embedded sensors, the price of instrumentation and the complexity of the related algorithm.

In this perspective, a new fault detection method is proposed and studied in this article. It still relies on voltage measurement but is no longer based on frequency signature. It intends to make use of the small disparity of temperature and the non-uniform distribution of reactants along the stack. The fact is that many authors pointed out the cell discrepancies throughout the stack which depend on the operating conditions [19]. Some authors show that cell voltage is lower in the cells furthest from the fuel inlet of the stack (nearest to the air inlet) due to uneven gas distribution or water flooding [20]. Different experiments also point out that the central interior of the stack is hotter to its exterior, and subsequently drying mostly occurs in center cells [21,22]. In fact, Ramousse et al. [23] highlights that water in the cells is highly dependent on the temperature; as a result flooding occurs in cooler cells and drying in hotter cells. Based on these remarks, we suggest measuring the voltage of group of cells in the inlet, the center and the outlet of the stack. It will allow the detection of a fault when a voltage difference occurs and also permit identification using the shape of this voltage nonuniformity.

In this paper, we propose a differential voltage method, which only needs a few voltage sensors located judiciously along the FC stack and supervising only some particular cells or groups of cells. It can be performed on-line without disturbing the FC electric load neither with a small signal (EIS) nor with current interrupt (CI). Moreover, the measurements are associated with a simple algorithm which permits to get rid of many signal disturbances; for instance, load changes and slow dynamic phenomena (ageing effects...) don't affect the accuracy of the detection.

The paper is organized as follow. First a dynamic modeling of a cell is presented which allows performing the simulations and studying the behavior of the PEM fuel cell when a fault occurs. Then, the paper focuses on the fault detection and identification method applied to the multi-cell stack. The originally developed approach is first simulated in drying and flooding cases. In a second step, the method is experimented and validated on a 20-cell PEMFC test bench in the particular case of stack flooding. Finally the advantage of the method is discussed and compared to EIS and CI techniques.

\section{Fuel cell modeling and polarization signature}

\subsection{Fuel cell modeling: application to a 20-cell PEMFC}

Some work has already been reported in the literature, static and dynamic modeling based on empirical equations was given by [1,24-27]. The voltage drop across the fuel cell (FC) can be written as a function of the activation, ohmic and concentration overvoltages given by (1) for one cell:

$$
V_{\text {cell }}=E-\eta_{\text {act }}-\eta_{\text {ohm }}-\eta_{\text {conc }}
$$

With $E$ the electromotive force given using the Nernst equation:

$$
\begin{aligned}
E=1.229 & -8.5 \times 10^{-4}\left(T_{f c}-298.15\right)+4.3085 \times 10^{-5} \\
\times & T_{f c}\left(\ln \left(P_{H 2}\right)+0.5 \ln \left(P_{O 2}\right)\right)
\end{aligned}
$$

$\mathrm{T}_{\mathrm{fc}}$ is the fuel cell stack temperature; $\mathrm{P}_{\mathrm{H} 2}$ and $\mathrm{P}_{\mathrm{O} 2}$ are the partial pressures of hydrogen and oxygen respectively (in bar).

The activation voltage losses represent the fact that some energy is needed to generate a reaction product. They are obtained by the Tafel equation [1]:

$$
\eta_{a c t}=A \cdot \ln \left(\left(J+J_{n}\right) / J_{0}\right)
$$

with

$$
A=\left(R T_{f_{c}}\right) /(2 \alpha F)
$$

$\mathrm{J}$ is the fuel cell current density, $\mathrm{J}_{\mathrm{n}}$ the leakage current density, $\mathrm{J}_{0}$ the exchange current density, $\mathrm{R}$ the perfect gas constant, $\alpha$ the charge transfer coefficient and F the Faraday's constant. 
The ohmic voltage losses are due to the resistance for both electronic and ionic currents. They result in a slow and linear voltage drop with an increasing current. The main parameter of this voltage drop is the membrane resistance $R_{\text {mem }}$ :

$$
\eta_{\text {ohm }}=R_{m e m} . J
$$

The concentration voltage losses are due to the reduction of the reactant concentration at the electrode surface induced by reactants consumption. This irreversibility becomes significant at high current density and the related overvoltage is obtained empirically:

$$
\eta_{\text {conc }}=m \cdot \exp (n \mathrm{~J})
$$

$\mathrm{m}$ and $\mathrm{n}$ are constants depending on the construction of the cell. It is useful to formulate the real voltage of the cell when there is no current; this voltage is named the open circuit voltage (OCV). Using (2) and (3), the open current voltage $\mathrm{E}_{\mathrm{ocv}}$ can be computed as follows:

$$
\begin{aligned}
& E_{o c v}=1.229-8.5 \times 10^{-4}\left(T_{f c}-298.15\right)+4.3085 \times 10^{-5} \\
& \times T_{f c}\left(\ln \left(P_{H 2}\right)+0.5 \ln \left(P_{O 2}\right)\right)+A \ln \left(J_{0}\right) \\
& \eta_{\text {act } 2}=A \cdot \ln \left(J+J_{n}\right)
\end{aligned}
$$

More precisely the cell voltage becomes:

$$
V_{\text {cell }}=E_{\text {ocv }}-\eta_{\text {act } 2}-\eta_{\text {ohm }}-\eta_{\text {conc }}
$$

Concentration of charges (electrons and $\mathrm{H}^{+}$ions) on the active surface (electrode and electrolyte surface) greatly influences the probability of reaction. This build-up of charges takes time to establish, drives non-faradic current and depends on the load current. Consequently during current transient, overvoltage does not change instantaneously. This phenomenon is complex and known as charge double layer; it can be modeled by a capacitor $[25,28]$.

In the dynamic model, the double layer capacitor is placed in parallel to the sources representing electrochemical voltage losses $\left(\eta_{\text {act2 }}\right.$ and $\left.\eta_{\text {conc }}\right)$. That is the reason why we have to modify the model elements. As a matter of fact, the fuel cell current density $\mathbf{J}$ is shared between the double layer capacitor and $\eta_{\text {act2 }}, \eta_{\text {conc }}$. Then the current in the voltage loss branch $\left(J_{f}\right)$ needs to be calculated. For that purpose, we proceed as follows:

$\eta_{\text {act2 }}$ is replaced by a current source, called $J_{f}$, controlled by

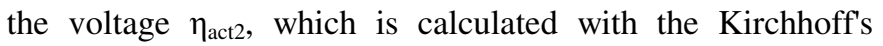
voltage law:

$$
\begin{gathered}
\eta_{a c t 2}+\eta_{c o n c}=V_{c d l} \\
\eta_{a c t 2}=V_{c d l}-\eta_{c o n c}
\end{gathered}
$$

$\mathbf{J}_{\mathrm{f}}$ is calculated thanks to (8)

$$
J_{f}=\exp \left(\eta_{a c t 2} / A\right)-J_{n}
$$

$\eta_{\text {conc }}$ is a voltage source controlled by $\mathbf{J}_{\mathrm{f}}$. The ohmic loss is modeled by a resistor. The model representation with the

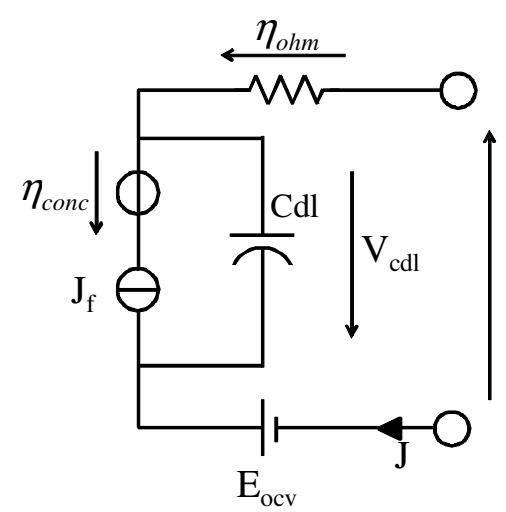

Fig. 1. Dynamic FC model: Representation of the double layer phenomenon.

The cell model is tuned with parameters given in Tab 1 . In order to have the fuel cell voltage, $\mathrm{V}_{\text {cell }}$ is multiplied by the number of cells. Figure 2 shows the polarization curve of the simulated model compared with a polarization curve obtained by experimental measurement on a 20-cell stack. The experimental polarization curve is obtained as follow: first fuel cell is set to nominal point ( stack temperature $=60^{\circ} \mathrm{C}, \mathrm{H}_{2} /$ $\mathrm{O}_{2}$ stoichiometry $=2 / 4, \mathrm{H}_{2} / \mathrm{O}_{2}$ hygrometry $=14 / 22 \%$ ). Then current is reduce from 60 to $0 \mathrm{~A}$ in ten minutes (ramp current $=$ $-0.1 \mathrm{~A} / \mathrm{s})$. As shown, the simulated curve fits in accordance with the experimental curve.

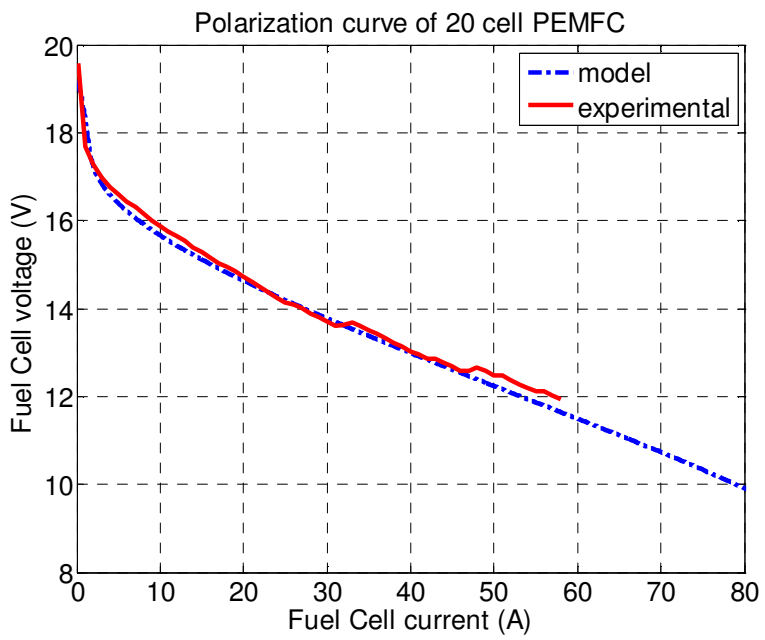

Fig. 2. Polarization curves of the experimented PEMFC stack and its related model.

Tab $1:$ Parameters used in the FC analytical electrical model

\begin{tabular}{|l|l|l||l|l|l|}
\hline$\alpha$ & Charge transfer coefficient & 0.44 & $\mathrm{C}_{\mathrm{dl}}$ & Double layer capacity & $50 \mathrm{mF} / \mathrm{cm}^{2}$ \\
\hline $\mathrm{m}$ & Concentration coefficient & $2.11 \times 10^{-5}$ & $\mathrm{~F}$ & Faraday's constant & $9.65 \times 10^{4} \mathrm{C} / \mathrm{mol}$ \\
\hline $\mathrm{n}$ & Concentration coefficient & $8 \times 10^{-3}$ & $\mathrm{R}$ & Perfect gas constant & $8.314472 \mathrm{~J} / \mathrm{mol} / \mathrm{K}$ \\
\hline $\mathrm{S}_{\text {cell }}$ & Cell surface & $100 \mathrm{~cm}^{2}$ & \multicolumn{5}{|l|}{} \\
\hline $\mathrm{R}_{\mathrm{mem}}$ & Membrane resistance & $300 \times 10^{-6} \mathrm{k} \Omega \cdot \mathrm{cm}^{2}$ & $\mathrm{Tfc}$ & Fuel cell temperature & $333.15 \mathrm{~K}$ \\
\hline $\mathrm{J}_{\mathrm{n}}$ & Leakage current density & $3 \mathrm{~mA} / \mathrm{cm}^{2}$ & $\mathrm{P}_{\mathrm{H} 2}$ & Hydrogen partial pressure & $0.93 \mathrm{bar}$ \\
\hline $\mathrm{J}_{0}$ & Exchange current density & $4 \times 10^{-4} \mathrm{~mA} / \mathrm{cm}^{2}$ & $\mathrm{P}_{\mathrm{O} 2}$ & Oxygen partial pressure & $0.17 \mathrm{bar}$ \\
\hline
\end{tabular}




\subsection{Polarization signature}

The work described in this article focuses on two kinds of fault: membrane drying and cell flooding. A drying, due to insufficient water content in the membrane, increases its resistance [22,29]. In case of a flooding, del Real et al. [24] explain that the water forms a thin film blocking part of the active fuel cell area. This phenomenon results in a lower apparent active area [30,31] and thus a higher current density which increases over voltages.

In general faults don't occur in the entire stack but only affect a few cells [18]. The impact on a single cell voltage is shown in Fig. 3. Plot (A) shows the cell polarization curve in rated conditions. (B) displays the polarization curve of the same cell when membrane drying occurs: the dried membrane resistance is increased by 1.5 compared to the rated value [8]. (C) illustrates the polarization curve of this cell when membrane flooding happens: the active area was reduced to $80 \%$, this will act on the cell current density according to this relation $J=I_{f c} /\left(S_{\text {cell }} * k\right)$ with $\mathrm{k}=0.8$ the degree of reduced active area [24]. As already described in [32], the voltage drop is similar either in the drying case or in flooding circumstances. The V-I characteristics become different only when the cell voltage is lower than its minimum voltage $(0.4 \mathrm{~V})$. The fuel cell should not be used under this voltage [33].

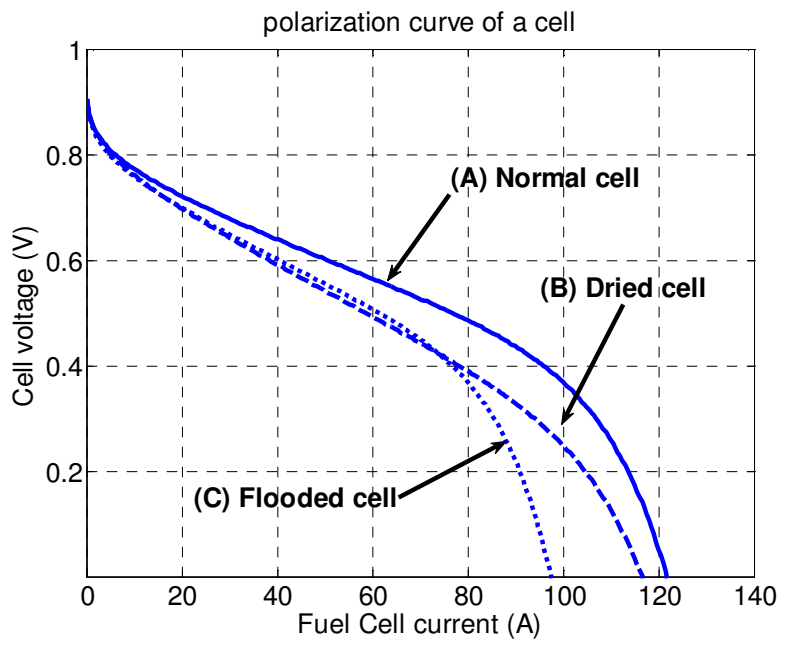

Fig. 3. Different polarization curves of a cell obtained by simulation.

\section{Fault detection for a power stack}

\subsection{Monitoring for a power stack}

Stack-level investigations offer more opportunities than single cell level analysis. In particular, $[19,23,34]$ show that flooding or drying only affects some localized cells or groups of cells. In case of a high dew point temperature, humidified air quickly condenses at the inlet of the stack. Furthermore water produced by the electrochemical reaction can easily accumulate at the outlet of the stack. Eckl et al. [22] demonstrates that, during flooding experiments on a 20-cell stack, the most perturbed cells were the cells 3 and 5 . Hernandez's experiments [34] pointed out, with a 20-cell stack, voltage degradation due to flooding in cells 4, 5, 6 and 18, 20. In Corbo's experiments on a 34-cell stack [35], flooding has a great effect on the $6^{\text {th }}$ and $28^{\text {th }}$ cells. Conversely the center of the stack is hotter than its extreme parts; the presence of liquid water is lower. In Park's drying experiments on an 8-cell stack, the most affected cells were the $4^{\text {th }}, 5^{\text {th }}$ and $6^{\text {th }}[29]$. Eckl gives the same observation with a 20-cell stack [22], where cell voltages $\mathrm{V}_{9}, \mathrm{~V}_{11}$ and $\mathrm{V}_{13}$ were deeply disturbed by a drying.

Hence a flooding may occur in the inlet and outlet of the stack while a drying may occur in the center of the stack. That is the reason why, instead of monitoring all the cells, it could be judicious to monitor only a group of representative cells: cells located at the inlet and the outlet in order to detect a flooding, and cells in the center of the stack for detecting a drying.

\subsection{Fault detection and identification (FDI) strategy using the differential method: approach by simulation}

Referring to the previous studies mentioned in the article, it appears relevant to instrument with voltage sensors three main areas of the stack: the inlet, the outlet and the center (Fig. 4). In this case, the detection principle is based on the monitoring of a differential between the voltage in the center of the stack $\left(\mathrm{V}_{\text {center }}\right)$ and the inlet/outlet voltages (resp. $\left.\mathrm{V}_{\text {inlet }}, \mathrm{V}_{\text {outlet }}\right)$. This principle allows to generate a new state-of-health indicator of the fuel cell stack. In the case of no fault, all voltages are constant or drop similarly due to load variation: the differential voltages equal zero. If a drying appears, only $\mathrm{V}_{\text {center }}$ drops and the two differential voltages become positive. However, if a flooding occurs, the inlet and/or the outlet voltage drops leading to a decrease of one or two differential voltages.

Using the differential method, the FC stack can be assimilated to a voltage sensor. Its characteristic is to provide two key signals representative of the state of health. The feedback information is simple, fast and based on the real-time operating conditions without adding any external disturbance. Moreover the method can be applied also when the operating conditions are slightly modified.

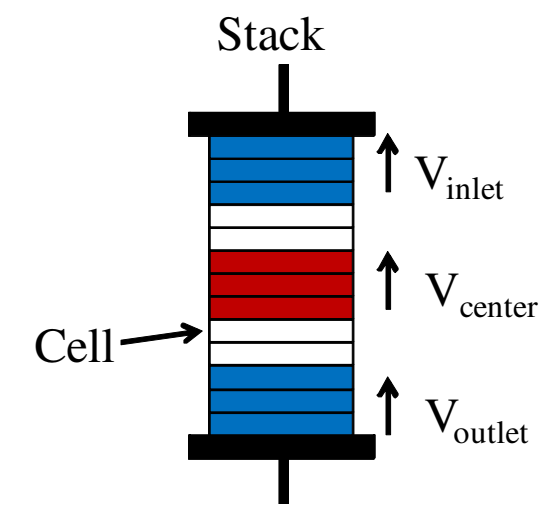

Fig. 4. Principle of monitored cells for a fuel cell stack.

As a first approach, the proposed detection method is validated by numerical simulations.

\subsubsection{Fuel cell model enhancement}

In order to study the differential method, the FC stack is modeled in the following way: firstly, FC is segmented into 5 segments of $3,6,3,5,3$ cells distributed from the inlet to the outlet of the stack. Previous cell model is used to calculate 
each segment voltage $\mathrm{V}_{\text {st, } \mathrm{i}}$. Then electrical model of segment $\mathrm{i}$ is coupled with thermal one as represented in Fig. 5.

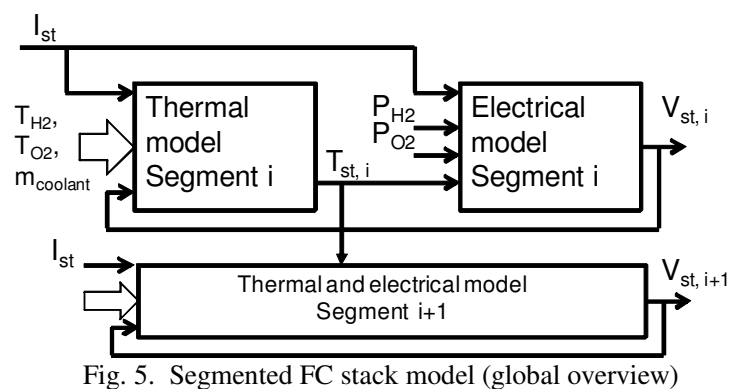

The temperature of one stack segment is calculated as follow $[24,36]:$

$$
\begin{aligned}
m_{s t} C_{s t} \frac{\partial T_{s t}}{\partial t}= & \\
& \quad H_{\text {react }}-Q_{\text {cool }}-Q_{\text {conv }}-Q_{\text {rad }}-P_{E l}+Q_{\text {cond }}
\end{aligned}
$$

$\mathrm{m}_{\mathrm{st}} \mathrm{C}_{\mathrm{st}}$ is the thermal capacity of the system, $\mathrm{T}_{\mathrm{st}}$ is the stack segment temperature.

With $\dot{H}_{\text {react }}$ the energy of the electrochemical reaction:

$$
\dot{H}_{\text {react }}=\dot{m}_{H 2} \Delta h_{H 2}+\dot{m}_{O 2} \Delta h_{O 2}-\dot{m}_{H 2 O}\left(h_{f}^{0} \Delta h\right)_{H 2 O}
$$

$\mathrm{H}_{\mathrm{f}}^{0}$ is the mass specific enthalpy of formation and $\dot{m}$ denotes the mass flow of the substance:

$$
\begin{aligned}
\dot{m}_{H 2} & =M_{H 2} N_{c e l l} \frac{I_{s t}}{2 F} \\
\dot{m}_{O 2} & =M_{O 2} N_{\text {cell }} \frac{I_{s t}}{4 F} \\
\dot{m}_{H 2 O} & =M_{H 2 O} N_{\text {cell }} \frac{I_{s t}}{2 F}
\end{aligned}
$$

$\mathrm{M}$ is the molecular mass en $\mathrm{kg} / \mathrm{mol}, \mathrm{N}_{\text {cell }}$ is the stack segment number of cell, $\mathrm{F}$ the Faraday constant and $\mathrm{I}_{\mathrm{st}}$ the current stack.

$\Delta h$ is the mass specific enthalpy difference from the present state to the reference state:

$$
\begin{gathered}
\Delta h_{H 2}=C_{p H 2}\left(T_{H 2 \text { in }}-T_{0}\right) \\
\Delta h_{O 2}=C_{p O 2}\left(T_{\text {airin }}-T_{0}\right) \\
\Delta h_{H 2 O}=C_{p H 2 O}\left(T_{\text {airout }}-T_{0}\right)
\end{gathered}
$$

$\mathrm{C}_{\mathrm{p}}$ are the specific heat energies, $\mathrm{T}_{\mathrm{h} 2}$ in, $\mathrm{T}_{\text {air in }}$ and $\mathrm{T}_{\text {air out }}$ are the inlet $\mathrm{H} 2$ gas temperatures, the inlet air gas temperature and the outlet air gas temperature.

Outlet gas temperature is calculated thanks to:

$$
T_{\text {air out }}=2 T_{\text {air }}^{\text {stack }}-T_{\text {air in }}
$$

Where:

$$
T_{\text {air }}^{\text {stack }}=T_{s t}-\frac{\dot{H}_{\text {react }}-P_{E l}}{k_{T}}
$$

Here it is assumed that the temperature difference between the FC and the cathode air is proportional to the total waste heat of the reaction. The constant proportionality $\mathrm{k}_{\mathrm{T}}$ can be determined experimentally.

$\mathrm{Q}_{\text {conv }}$ and $\mathrm{Q}_{\mathrm{rad}}$ are the heat transfer to the surrounding area by a convective and a radiative heat flow.

$$
\begin{aligned}
Q_{c o n v} & =h_{a m b} A_{a m b}\left(T_{s t}-T_{a m b}\right) \\
Q_{\text {rad }} & =\varepsilon \sigma A_{a m b}\left(T_{s t}^{4}-T_{a m b}^{4}\right)
\end{aligned}
$$

$\mathrm{h}_{\mathrm{amb}}$ is the heat transfer coefficient of the FC, $\mathrm{A}_{\mathrm{amb}}$ denotes the outer surface of the body, $\varepsilon$ is the emissivity of the body, $\sigma$ is the Stefan-Boltzmann constant and $\mathrm{T}_{\mathrm{amb}}$ represents the temperature of the environment.

The electric power of the system equals the product of the stack segment voltage with the current:

$$
P_{E l}=V_{s t} I_{s t}
$$

$\mathrm{Q}_{\text {cool }}$ represent the heat transfer rate from the body to the coolant:

$$
Q_{\text {cool }}=h_{\text {cool }} A_{\text {cool }}\left(T_{s t}-T_{\text {cool }}\right)
$$

with $\mathrm{A}_{\text {cool }}$ the heat transfer area, $\mathrm{T}_{\text {cool }}$ the temperature of the coolant inside the FC and $h_{\text {cool }}$ the heat transfer coefficient given by :

$$
h_{\text {cool }}=K_{h}\left(\dot{m}_{\text {coolant }}\right)
$$

This heat transfer coefficient is a function of the coolant mass flow $\dot{m}_{\text {coolant }}$, the coefficient $\mathrm{K}_{\mathrm{h}}$ has to be determined experimentally.

The temperature of the coolant inside the FC is calculated as follow:

$$
m_{\text {cool }} C_{\text {cool }} \frac{\partial T_{c o o l}}{\partial t}=\Delta \dot{H}_{c o o l}+Q_{\text {cool }}
$$

$\mathrm{m}_{\text {cool }} \mathrm{C}_{\text {cool }}$ is the thermal capacity of the coolant system in the FC segment

$\Delta \dot{H}_{\text {cool }}$ is the enthalpy difference of the coolant flow :

$$
\Delta \dot{H}_{\text {cool }}=\dot{m}_{\text {coolant }} C_{p H 2 O}\left(T_{\text {cool in }}-T_{\text {cool }}\right)
$$

with $\mathrm{T}_{\text {cool in }}$ the inlet coolant temperature.

Lastly conductive effects between one segment to its neighbor is given by: 


$$
Q_{\text {conv }}=\left\{\begin{array}{l}
\frac{D}{\delta}\left(T_{2}-T_{s t}\right) \text { for segment } 1 \\
\frac{D}{\delta}\left(T_{n+1}+T_{n-1}-2 T_{s t}\right) \text { for segment } n=2,3,4 \\
\frac{D}{\delta}\left(T_{4}-T_{s t}\right) \text { for segment } 5
\end{array}\right.
$$

$\mathrm{D}$ is the transfer coefficient and $\delta$ the thickness between two segments. All parameters required for the thermal model are summarized in Tab.2.

Temperature along the stack is plotted in Fig. 6. H2 and Air gas temperature is set to $40^{\circ} \mathrm{C}$, ambient temperature is $25^{\circ} \mathrm{C}$. Coolant inlet temperature is $50^{\circ} \mathrm{C}$. FC current is set to $30 \mathrm{~A}$.

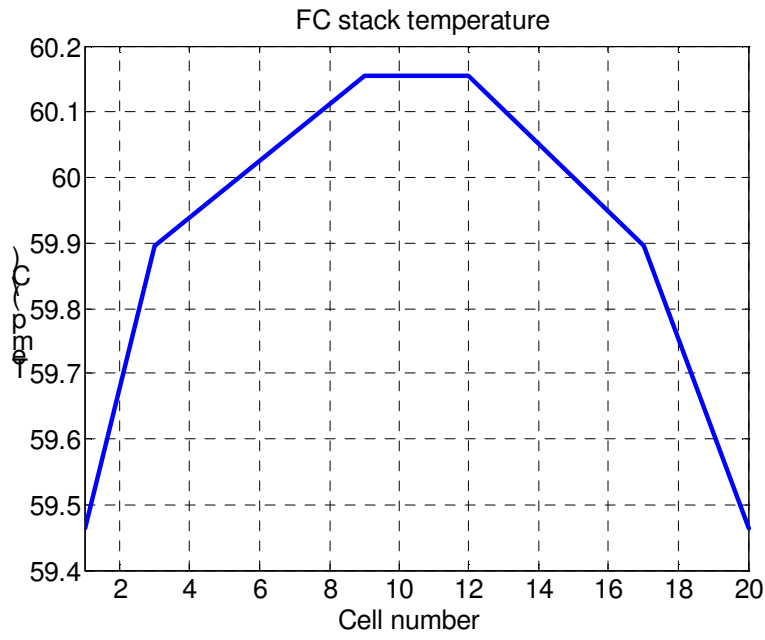

Fig. 6. Fuel cell stack temperature profile versus cell number.

As expected the center of the FC is hotter than extremity.

A temperature raise of $0.7^{\circ} \mathrm{C}$ in the center of the stack increases the vapor partial pressure by $2.4 \%$. Then less liquid water should be present in the center of the fuel cell.

\subsubsection{Simulation results}

Fig. 7 shows the detection method in the case of a flooding. Flooding occurs at 3 seconds in the inlet and outlet of the stack, and water is slowly accumulated in the cells until the active area is reduced to $80 \%$, while inlet and outlet monitored voltage drop slowly. The global stack voltage does not drop significantly. On the contrary, monitoring the three groups of cells makes it possible to detect the early fault. The differential voltages $\left(\mathrm{V}_{\text {intlet }}-\mathrm{V}_{\text {center }}\right)$ and $\left(\mathrm{V}_{\text {outlet }}-\mathrm{V}_{\text {center }}\right)$ are negative and are falling slowly as the water content increases.
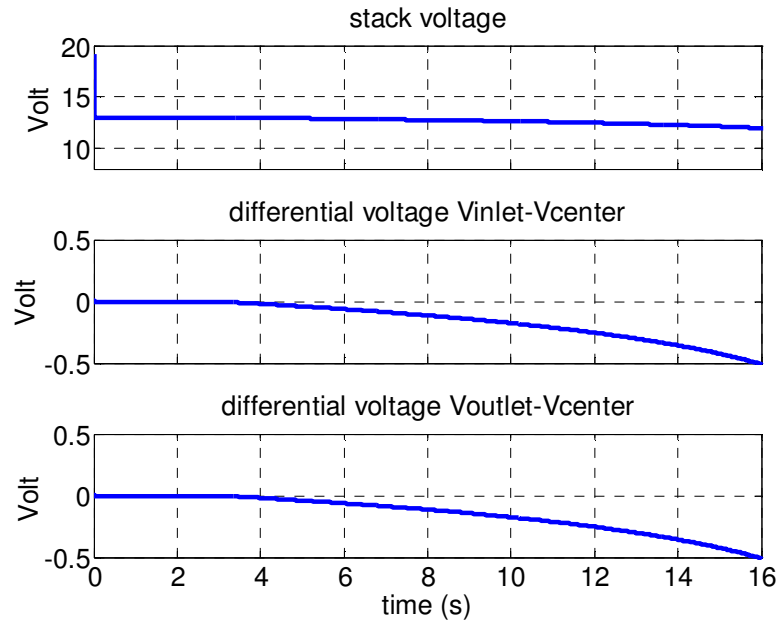

Fig. 7. Principle of monitored cells: flooding case.

Fig. 8 shows the case of a drying affecting the center cells. In this case, because the center cells are drying, their resistances increase gradually up to a 1.5 factor resulting in a voltage drop of center cells only. In that case the two differential voltages are positive and increase. In this case too, the global stack voltage does not drop significantly, but thanks to the differential voltages, the fault can be detected in a sensitive

\begin{tabular}{|c|c|c|c|c|c|}
\hline $\mathrm{m}_{\mathrm{st}}$ & $\begin{array}{l}\text { Mass of the stack } \\
\text { segment }\end{array}$ & $1.4 \mathrm{~kg}$ & $\mathrm{~h}_{\mathrm{amb}}$ & $\begin{array}{l}\text { Heat transfer coefficient } \\
\text { of FC }\end{array}$ & $3.9 \mathrm{~W} \mathrm{~m}^{-2} \mathrm{k}^{-1}$ \\
\hline $\mathrm{C}_{\mathrm{st}}$ & Stack specific heat & $1300 \mathrm{~J} \mathrm{~kg}^{-1} \mathrm{~K}^{-1}$ & $\mathrm{~A}_{\mathrm{amb}}$ & $\begin{array}{l}\text { Convection exchange } \\
\text { surface }\end{array}$ & $0.023 \mathrm{~m}^{2}$ \\
\hline $\mathrm{M}_{\mathrm{H} 2, \mathrm{O} 2, \mathrm{H} 2 \mathrm{O}}$ & $\begin{array}{l}\text { Molecular mass of } \mathrm{H}_{2}, \\
\mathrm{O}_{2} \text { and } \mathrm{H}_{2} \mathrm{O}\end{array}$ & $\mathrm{Kg} / \mathrm{mol}$ & $\varepsilon$ & Emissivity of the body & 0.9 \\
\hline $\mathrm{N}_{\text {cell }}$ & $\begin{array}{l}\text { Number of cell in the } \\
\text { segment }\end{array}$ & & $\sigma$ & $\begin{array}{l}\text { Stefan-Boltzmann } \\
\text { constant }\end{array}$ & $5.67810^{-8} \mathrm{~W} \mathrm{~m}^{-2} \mathrm{~K}^{-4}$ \\
\hline $\mathrm{Cp}_{\mathrm{H} 2, \mathrm{O} 2, \mathrm{H} 2 \mathrm{O}}$ & $\begin{array}{l}\text { Specific heat energy of } \\
\mathrm{H}_{2}, \mathrm{O}_{2} \text { and } \mathrm{H}_{2} \mathrm{O}\end{array}$ & $\mathrm{J} \mathrm{kg}^{-1} \mathrm{~K}^{-1}$ & $\mathrm{~A}_{\text {cool }}$ & $\begin{array}{l}\text { Heat transfer area of } \\
\text { coolant }\end{array}$ & $0.011 \mathrm{~m}^{2}$ \\
\hline $\mathrm{T}_{0}$ & Reference temperature & $298.15 \mathrm{~K}$ & $\mathrm{~K}_{\mathrm{h}}$ & Heat transfer coefficient & $2.1610^{5} \mathrm{~W} \mathrm{~kg}^{-2} \mathrm{k}^{-1}$ \\
\hline $\mathrm{K}_{\mathrm{T}}$ & Constant proportionality & $340 \mathrm{~W} \mathrm{~K}^{-1}$ & $\mathrm{~m}_{\mathrm{cool}} \mathrm{C}_{\mathrm{cool}}$ & $\begin{array}{l}\text { Thermal capacity of the } \\
\text { coolant system }\end{array}$ & $110 \mathrm{~J} \mathrm{k}^{-1}$ \\
\hline $\mathrm{D}$ & $\begin{array}{l}\text { Heat transfer coefficient } \\
\text { between } 2 \text { FC segments }\end{array}$ & $0.35 \mathrm{~W} \mathrm{~m} \mathrm{k}^{-1}$ & $\dot{m}_{\text {coolant }}$ & Coolant mass flow & $0.08 \mathrm{~kg} \mathrm{~s}^{-1}$ \\
\hline$\delta$ & $\begin{array}{l}\text { Thickness between } 2 \text { FC } \\
\text { segments }\end{array}$ & $510^{-3} \mathrm{~m}$ & $\mathrm{H}_{\mathrm{f}}^{0}$ & $\begin{array}{l}\text { Mass specific enthalpy } \\
\text { of formation }\end{array}$ & $-1.5810^{7} \mathrm{~J} \mathrm{k}^{-1}$ \\
\hline
\end{tabular}
way.

Tab 2: Parameters used in the FC thermal model 

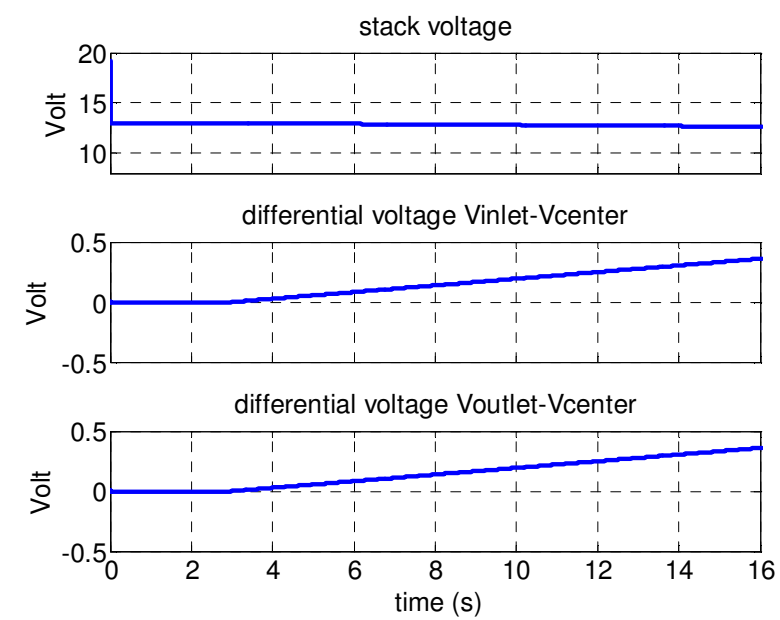

Fig. 8. Principle of monitored cells: drying case.

Simulation results demonstrate the validity of the technique on well known faults. However, it should distinguish between a real fault and a disturbance in order to prevent false alarm.

Fig. 9 shows the case of a load variation of a healthy stack in order to validate the detection principle during transient. In this occurrence, all cells are perturbed in the same way and thus their voltage drops are equal leading to a constant differential voltage.

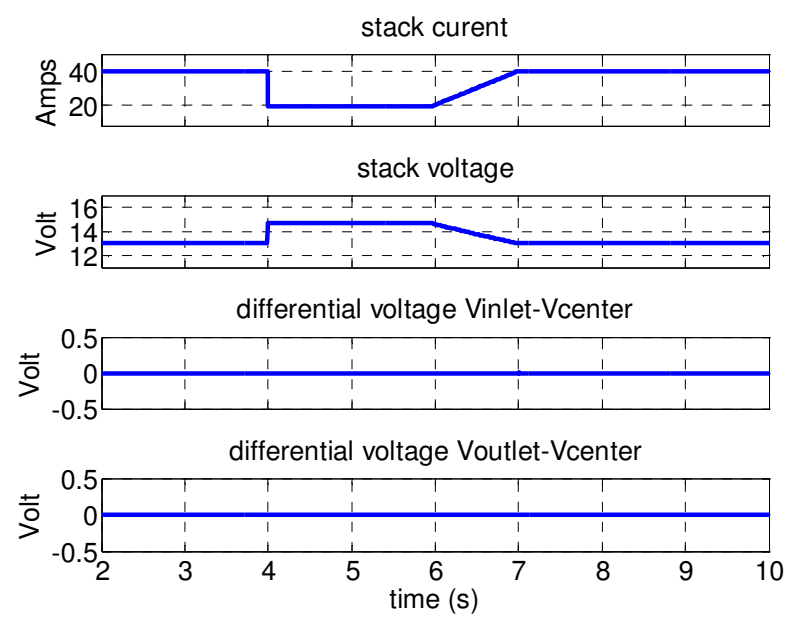

Fig. 9. Principle of monitored cells: healthy stack with current variation.

Thanks to the measurement of the three voltages representing the three key parts of a stack, this fault detection method reveals very sensitive. It allows detecting early fuel cell failure, before it completely affects the entire stack behavior. It requires a very low number of sensors, is a non intrusive technique and also does not perturb the stack functioning. Moreover, it could be easily implanted in embedded applications.

\section{Experimental validation}

Experimentations have been performed on a real FC stack in the FC LAB in Belfort. The PEMFC is a $500 \mathrm{~W}, 20$-cell, 100 $\mathrm{cm}^{2}$ stack from ZSW - UBZM manufacturer (Fig. 10). The objectives of these experiments are:

- To control that inlet and outlet voltage cells are negatively influenced during flooding.
To visualize which cells are flooded in each case.

- To choose cells representative of FC state of health and instrument them.

- $\quad$ To apply the differential method.

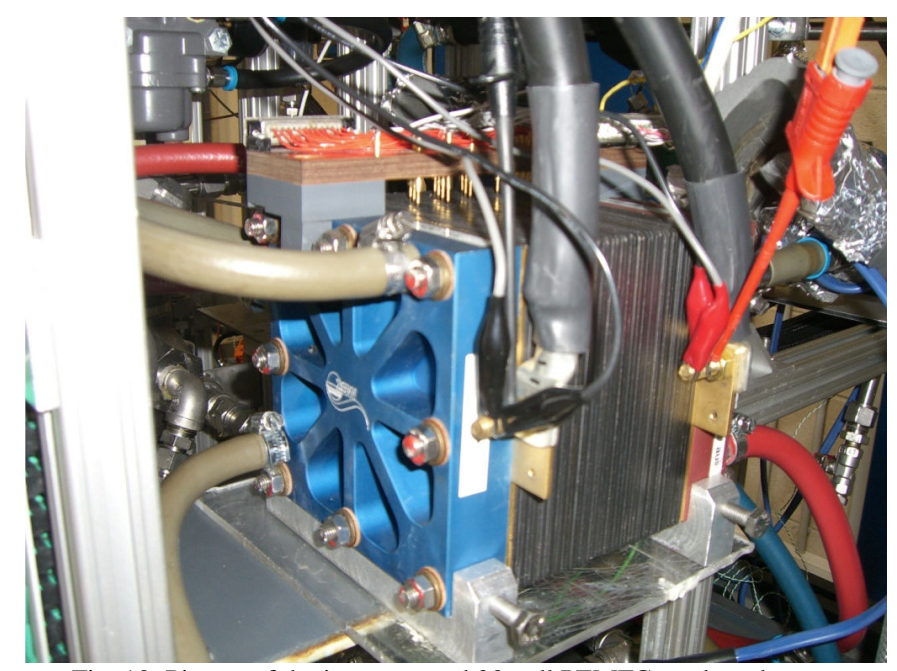

Fig. 10: Picture of the instrumented 20-cell PEMFC stack under test.

Many flooding experiments are performed at different operating conditions: different stack temperatures and hygrometry rates. Some experimental results are summarized in Tab. 3. It presents the cells with the greater voltage degradation due to flooding during all the experiments. White table cell correspond to cell voltage above $0.6 \mathrm{~V}$, blue colored table cell means that cell voltage drops between 0.5 and $0.6 \mathrm{~V}$. Finally, red table cell with a cross signify cell voltage drops under $0.5 \mathrm{~V}$.

This table points out that cells 4, 5, 6 and 18, 20 are always influenced by flooding. These results are in good agreement with previous observations. Ramousse et al. [23] experiment multiple floodings on a 65-cell stack: they obverse that the worst voltage degradation always affects the same cells. They show that this performance mismatch is due to a non uniform thermal distribution. The gas flow distribution plays also an important role in the flooding process [37]. In theory, all cells have the same air flow distribution but in reality bipolar plates are slightly different [38]. Moreover, the clamping pressure, due to stack assembly, modifies the air flow and plays an important role in FC performance and flooding phenomenon $[18,39]$. Thus, because of these material differences, some cells are more prone to flooding than others. Then we can consider that these cells are representative of FC state of health.

During the tests, in many occurrences, cell voltage 13 presents voltage degradation. This is not in agreement with previous observations, but an explanation could be the FC ageing. The stack has been previously tested for about 500 hours under different operating conditions. In normal conditions, this cell voltage was already lower than others; we suspect a possible degradation of its material. For example an increase of its channel friction would imply a lower gas flow in this cell and then an important flow disparity [38]. But we can't exclude possible flooding space cyclicity where, in long cell assembly, some cells could be affected by flooding in a cyclic location along the stack. Tests on others stacks should be performed in particular on large stack to validate this hypothesis. 
As explained in the previous section, it is judicious to monitor only 3 groups of cell voltage in order to detect a flooding or a drying. The choice of the number of measured cells is in fact a trade-off between easy sensor implementation by measuring sufficient voltage amplitude and the need of a good signal/noise ratio. In our case, 3 cells are monitored in the inlet (V4+V5+V6 named Vinlet), 3 cells in the center (V11+V12+V13 named Vcenter) and 3 cells in the outlet of the stack (V18+V19+V20 named Voutlet).

For the next step of this study, figures 11, 12 and 13 focus on the particular experiment number 5, performed under a flooding fault with the following conditions:

- Temperature of the stack: $40^{\circ} \mathrm{C}$

FC current: $40 \mathrm{~A}$

Air inlet hygrometry rate: $45 \%$

Each cell voltages are depicted in figure 11. Firstly flooded cell voltages drop smoothly because of water accumulation in the gas diffusion layer (GDL), and then the voltages behave regarding the characteristic of the flooding signature. Indeed, water droplet formation blocks the gas channel and causes the voltage drop owing to local gas starvation. Meanwhile, the inlet pressure increases. Finally gas pressure evacuates the droplet; as a result the voltage increases until the next droplet is generated. Water droplet formation and extraction, associated with local gas starvation [40] cause cell voltage oscillations.

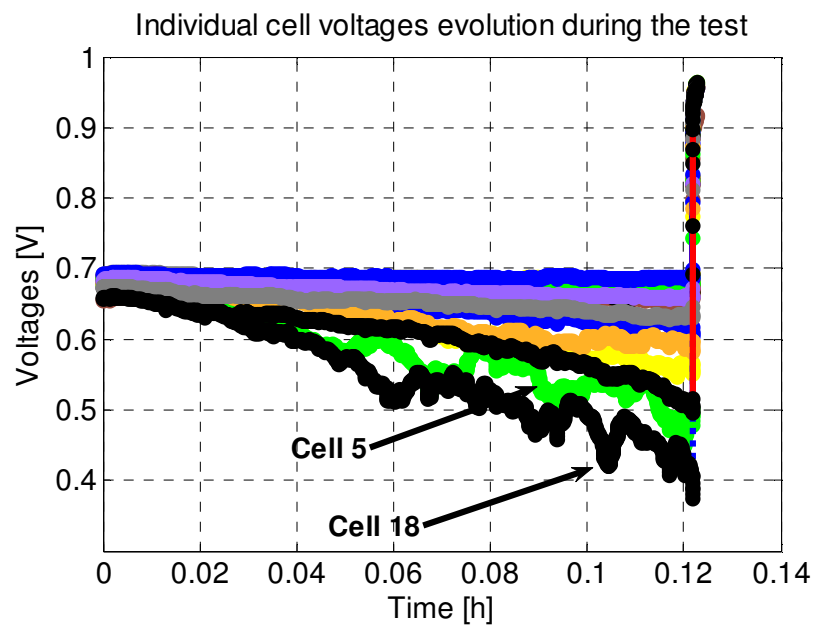

Fig. 11. Evolution of individual cell voltages.

At $\mathrm{t}=0.12 \mathrm{~h}$, the cell voltage 18 drops under the safety level set to $380 \mathrm{mV}$. Thus, so as not to degrade irreversibly the catalysts of FC materials [41,42], the stack is disconnected.

The cell voltage discrepancy is shown in Fig. 12. This figure illustrates the voltage drop during all the experiment. Thus 2 areas can be identified:

- When FC is delivering current: cell voltages are under 0.7 Volt.

- When FC is disconnected: cell voltages are on OCV (i.e. above $0.9 \mathrm{~V})$.

The voltage drop of the cells number 4, 5, 13, 18, 20 is clearly observed.

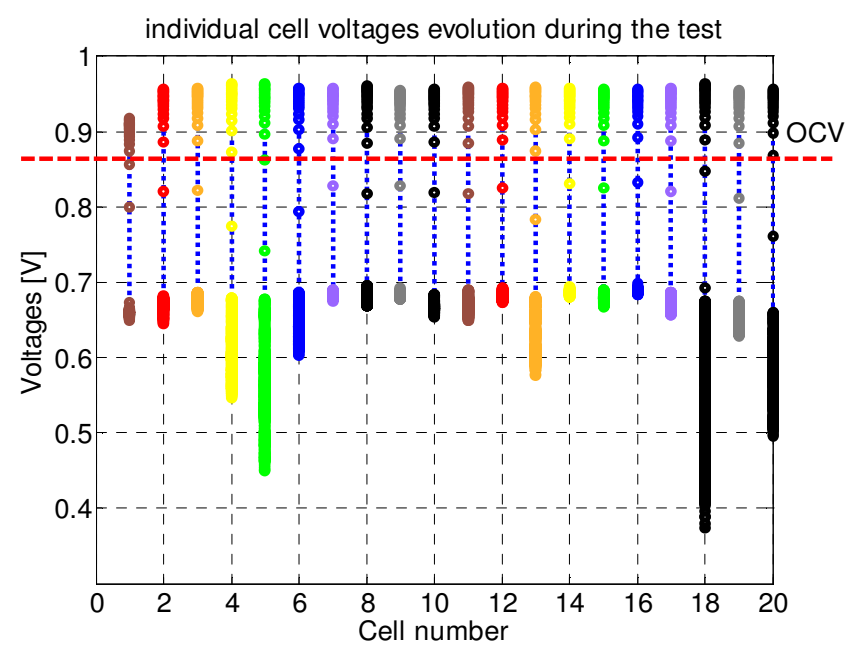

Fig. 12. Dispersion of individual cell voltages.

The two differential voltages are plotted figure 13 in the two upper subplots. Because the flooding takes place in the inlet and outlet cells, the differential measures are negative and slightly drop according to the flooding degree. This figure points out that the differential measures could detect the fault with a threshold set to $-0.2 \mathrm{~V}$, before the stack is disconnected because of a low cell voltage. This behavior is in agreement with the simulation study. It should be noted, that a fuel cell stack is affected by many degradation processes that are not yet well understood. Nevertheless the ageing phenomenon leads to a slow voltage decrease $[11,43]$ and an inhomogeneous voltage distribution along the stack even in nominal conditions. Consequently an aged fuel cell will present a mismatch difference voltage in normal operation mode. Hence, the ability to discriminate between ageing and malfunction leads to define a high level threshold. However this tuning has two drawbacks: on the one hand it may delay the detection alarm, on the other hand it may be not enough accurate to perform the detection.

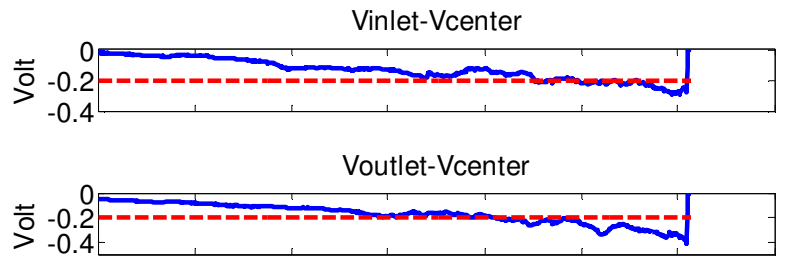

Vinlet-Vcenter with high pass filter

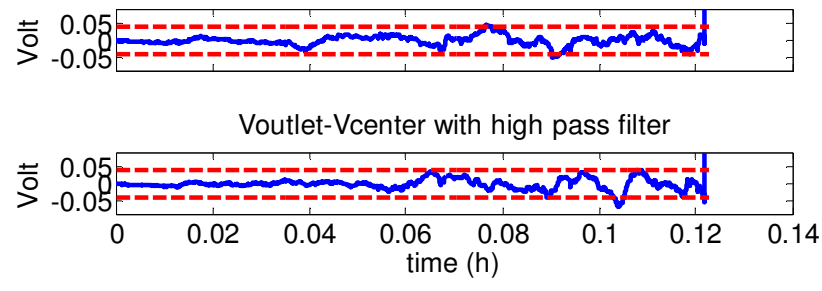

Fig. 13. Differential and filtered differential measures for cell voltages with their thresholds.

Figure 11 also points out the erratic voltage behavior owing to the water droplet. That is the reason why we suggest to filter differential measures with a high pass filter in order to get rid of the slow voltage derivation and only visualize the voltage oscillation due to water propagation. As droplet formation and extraction are slow phenomena, high pass cut-off frequency is 
set to $0.8 \mathrm{mHz}$. Filtered measures are displayed figure 13 in the two lower subplots. They highlight an increase of the oscillation magnitude along with the flooding. This could be a new criterion to improve flooding detection in terms of rapidity and robustness regarding rejection of perturbation (load variation and ageing effect). For instance a $0.04 \mathrm{~V}$ threshold allows a faster detection compared to the safety level procedure which requires each cell monitoring. The filtered data reveal that the proposed detection method is twice faster.

To conclude, the differential method is a non intrusive fault detection technique. It requires only 3 voltage sensors, is easy to implement and is cost-effective. Namely it allows to detect precisely and quickly flooding phenomenon (illustrated experimentally) without any sophisticated instrumentation or complex data post-processing. Study needs to be improved by performing EIS in order to prove that the PEMFC is under flooding condition. Further investigations have to be done on cell number 13 about its low voltage and its irregular behavior.

\section{Conclusion and perspectives}

The objective of the paper was to investigate voltage monitoring for the detection of common faults occurring in a PEMFC stack. To enhance stack lifetime it is important to realize fast fault detection identification (FDI) in order to remain as close as possible to the optimal operating conditions. Additionally, FDI implementation should be simple, reliable and non-intrusive. In mass market applications, the cost is also an important criterion.

Monitoring cell voltages gives information on the state of health but its implementation in a power stack can be rather complex because of the high number of cells. Subsequently, space distribution discrepancies throughout the FC stack when a fault occurs provide promising and encouraging results regarding cost issues, low number of sensors and quality of delivered information. The proposed differential method, using judiciously placed sensors was tested during flooding conditions. It gives a fast and relevant feed-back on the fault detection and identification. Its main advantage relies on its principle: indeed it directly uses the stack as a sensor and takes advantage of its electrical signals while operating.

Other techniques like electrochemical impedance spectroscopy (EIS) or current interrupt (CI) also monitor cell voltages, but are founded on a "perturb and observe" approach. On the one hand the CI method strongly disturbs the output power delivered to the load and hence requires an important auxiliary storage device. On the other hand EIS is based on small AC signal injection and weakly perturbs the stack power. Its main drawback relies on signal analysis which is based on steady state assumption and needs time to be performed. For the drying case, the membrane resistance monitoring makes sense. It can be evaluated with a high frequency disturbing signal inherently generated by the interface DC-DC converter for instance. That is the reason why EIS is effective and fast in this occurrence. However flooding circumstances are initiated by MEA water droplet and involves mass-transportation phenomenon. This fluidic phenomenon has a high time response and thus needs very small frequency superimposed AC perturbation. Moreover signal processing enabling flooding detection is also timeconsuming. It makes EIS flooding recognition long and for this reason very sensitive to load changes.

On the contrary our study demonstrates that the differential technique doesn't modify the output power and provides fast detection because it relies directly on the stack space signature. Tests performed on a 20-cell PEMFC stack validate this original differential method especially for flooding. Moreover, the differential method can also be implemented on-line for embedded applications (vehicle, demonstrator platform...) to give a quick feedback on the fuel cell state-ofhealth.

As a perspective, the method should be experimented on other fuel cell stacks to be widely validated: on recently manufactured or non aged stacks and particularly on larger multi-cell stacks. Thus, it should be interesting to investigate possible space cyclicity throughout a larger fuel cell stack. The differential method using voltage sensors could be improved by adding thermal sensors in the bipolar plates to get a thermal cartography of the stack, in order to improve the information content. Moreover it should be interesting to perform 3D simulations coupling together fluidic, thermal and water phenomena. At last, it would be appropriate to compare EIS and the differential method in terms of detection quickness and load perturbation rejection. It might lead to combine EIS for drying detection and the differential method for flooding.

\begin{tabular}{|c|c|c|c|c|c|c|c|c|c|c|c|c|c|c|c|c|c|c|}
\hline \multicolumn{3}{|c|}{ Cell } & \begin{tabular}{|l|l|}
1 & 2 \\
\end{tabular} & \begin{tabular}{|l|l|l}
2 & 3 & 4 \\
\end{tabular} & 5 & \begin{tabular}{l|l}
6 & 7 \\
\end{tabular} & \begin{tabular}{l|l|l}
7 & 8 & 9 \\
\end{tabular} & $\begin{array}{l}9 \\
9\end{array}$ & 11 & 12 & 13 & 14 & 15 & 16 & 17 & 18 & 19 & 20 \\
\hline & Operating condition & & & & & & & & & & & & & & & & & \\
\hline 1 & Temp $50^{\circ} \mathrm{C} \quad \mathrm{HR}=100 \% \mathrm{I}$ & $\mathrm{I}=30 \mathrm{~A}$ & & & $\mathrm{x}$ & & & & & & $\mathrm{x}$ & & & & & & & \\
\hline 2 & Temp $50^{\circ} \mathrm{C} \quad \mathrm{HR}=100 \% \mathrm{I}$ & $\mathrm{I}=40 \mathrm{~A}$ & & & & & & & & & & & & & & $\mathrm{x}$ & & $\mathrm{x}$ \\
\hline 3 & Temp $50^{\circ} \mathrm{C}$ HRvar & $\mathrm{I}=10 \mathrm{~A}$ & & & $\mathrm{x}$ & & & & & & & & & & & $\mathrm{x}$ & & \\
\hline 4 & Temp $50^{\circ} \mathrm{C} \quad \mathrm{HR}=100 \% \mathrm{I}$ & $\mathrm{I}=40 \mathrm{~A}$ & & & & & & & & & & & & & & & & \\
\hline 5 & Temp $40^{\circ} \mathrm{C} \quad \mathrm{HR}=45 \%$ & $\mathrm{I}=40 \mathrm{~A}$ & & & $\mathrm{x}$ & & & & & & & & & & & $\mathrm{x}$ & & \\
\hline 6 & Temp $40^{\circ} \mathrm{C} \quad \mathrm{HR}=56 \%$ & $\mathrm{I}=40 \mathrm{~A}$ & & & $\mathrm{x}$ & & & & & & & & & & & $\mathrm{x}$ & & $\mathrm{x}$ \\
\hline 7 & Temp $40^{\circ} \mathrm{C} \quad \mathrm{HR}=75 \%$ & $\mathrm{I}=40 \mathrm{~A}$ & & & $\mathrm{x}$ & & & & & & & & & & & $\mathrm{x}$ & & $\mathrm{x}$ \\
\hline 8 & Temp $40^{\circ} \mathrm{C} \quad \mathrm{HR}=96 \%$ & $\mathrm{I}=40 \mathrm{~A}$ & & & & & & & & & & & & & & $\mathrm{x}$ & & $\mathrm{x}$ \\
\hline 9 & Temp $40^{\circ} \mathrm{C}$ HRvar & $\mathrm{I}=40 \mathrm{~A}$ & & & $\mathrm{x}$ & & & & & & $\mathrm{x}$ & & & & & & & \\
\hline & Legend: & & & & & & & & & & & & & & & & & \\
\hline
\end{tabular}

Tab. 3 : Most impacted cell voltages during tests 


\section{References}

[1] J. Larminie and A. Dicks, Fuel cell systems explained, John Wiley \& Sons, 2003.

[2] H. Li, Y. Tang, Z. Wang, Z. Shi, S. Wu, D. Song, J. Zhang, K. Fatih, J. Zhang, H. Wang, Z. Liu, R. Abouatallah, and A. Mazza, "A review of water flooding issues in the proton exchange membrane fuel cell," Journal of Power Sources, vol. 178, 2008, pp. 103-117.

[3] S. Knights, "Aging mechanisms and lifetime of PEFC and DMFC," Journal of Power Sources, vol. 127, 2004, pp. 127-134.

[4] X. Xue, J. Tang, N. Sammes, and Y. Ding, "Model-based condition monitoring of PEM fuel cell using Hotelling T2 control limit," Journal of Power Sources, vol. 162, 2006, pp. 388-399.

[5] N. Yousfi-Steiner, P. Moçotéguy, D. Candusso, D. Hissel, A. Hernandez, and A. Aslanides, "A review on PEM voltage degradation associated with water management: Impacts, influent factors and characterization," Journal of Power Sources, vol. 183, 2008, pp. 260274.

[6] B. Wahdame, D. Candusso, F. Harel, X. François, M.-C. Péra, D. Hissel, and J.-M. Kauffmann, "Analysis of a PEMFC durability test under low humidity conditions and stack behaviour modelling using experimental design techniques," Journal of Power Sources, vol. 182, Aug. 2008, pp. 429-440.

[7] S. Wasterlain, "Approches expérimentales et analyse probabiliste pour le diagnostic de piles à combustible de type PEM," Ph.D thesis (in French), Université de Franche-Comté, Belfort, France, 2010.

[8] M. Hinaje, I. Sadli, J.-P. Martin, P. Thounthong, S. Raël, and B. Davat, "Online humidification diagnosis of a PEMFC using a static DC-DC converter," International Journal of Hydrogen Energy, vol. 34, 2009 pp. 2718-2723.

[9] D. Webb, "Measuring individual cell voltages in fuel cell stacks," Journal of Power Sources, vol. 103, Dec. 2001, pp. 54-60.

[10] G. Mulder, F. Deridder, P. Coenen, D. Weyen, and a Martens, "Evaluation of an on-site cell voltage monitor for fuel cell systems," International Journal of Hydrogen Energy, vol. 33, 2008, pp. 57285737.

[11] N. Guillet, S. Didierjean, A. Chenu, C. Bonnet, P. Carré, B. Wahdame, L. Dumercy, X. François, L. Girardot, F. Harel, D. Hissel, S. Besse, S. Boblet, V. Chaudron, A. De Bernardinis, G. Coquery, S. Escribano, and N. Bardi, "Scientific and Technological Progress Toward the Development of an 80kWe PEM Fuel Cell System for Transpor Applications," EVS'07 23rd Electrical Vehicles Symposium, Anaheim, California USA: 2007

[12] C. Bonnet, S. Didierjean, N. Guillet, S. Besse, T. Colinart, and P. Carré, "Design of an $80 \mathrm{kWe}$ PEM fuel cell system: Scale up effect investigation," Journal of Power Sources, vol. 182, 2008, pp. 441-448.

[13] A. De Bernardinis, F. Harel, L. Girardot, D. Candusso, D. Hissel, X François, G. Coquery, and S. Besse, "Experimental Dynamic Performance of a 30kW 90Cell PEFC Stack under Transportation Load Cycle Constraints," EFCF 2009, Lucerne, Switzerland: 2009, pp. 1-16.

[14] J.-P. Poirot-Crouvezier and F. Roy, "GENEPAC Project: Realization of a fuel cell stack prototype dedicated to the automotive application," WHEC, Lyon, France: 2006, pp. 1-5.

[15] K. Sekizawa, N. Kitamura, K. Manabe, Y. Nonobe, M. Kizaki, and K. Kojima, "Recent Advances in TOYOTA FCHV-adv Fuel Cell System," ECS Transactions, vol. 33, 2010, pp. 1947-1957.

[16] A. De Bernardinis, M.-C. Péra, J. Garnier, D. Hissel, G. Coquery, and J.-M. Kauffmann, "Fuel cells multi-stack power architectures and experimental validation of $1 \mathrm{~kW}$ parallel twin stack PEFC generator based on high frequency magnetic coupling dedicated to on board power unit," Energy Conversion and Management, vol. 49, 2008, pp. 2367-2383.

[17] P. Lin, P. Zhou, and C.W. Wu, "A high efficient assembly technique for large PEMFC stacksPart I. Theory," Journal of Power Sources, vol. 194 , Oct. 2009 , pp. $381-390$
[18] P. Rodatz, F. Büchi, C. Onder, and L. Guzzella, "Operational aspects of a large PEFC stack under practical conditions," Journal of Power Sources, vol. 128, 2004, p. 208-217.

[19] M. Miller and A. Bazylak, "A review of polymer electrolyte membrane fuel cell stack testing," Journal of Power Sources, vol. 196, Jan. 2011, pp. 601-613.

[20] W.H. Zhu, R.U. Payne, D.R. Cahela, and B.J. Tatarchuk, "Uniformity analysis at MEA and stack Levels for a Nexa PEM fuel cell system," Journal of Power Sources, vol. 128, Apr. 2004, pp. 231-238.

[21] J. Jang, H. Chiu, W. Yan, and W. Sun, "Effects of operating conditions on the performances of individual cell and stack of PEM fuel cell," Journal of Power Sources, vol. 180, May. 2008, pp. 476-483.

[22] R. Eckl, W. Zehtner, C. Leu, and U. Wagner, "Experimental analysis of water management in a self-humidifying polymer electrolyte fuel cell stack," Journal of Power Sources, vol. 138, Nov. 2004, pp. 137-144.

[23] J. Ramousse, K.P. Adzakpa, Y. Dubé, K. Agbossou, M. Fournier, A Poulin, and M. Dostie, "Local Voltage Degradations (Drying and Flooding) Analysis Through 3D Stack Thermal Modeling," Journal of Fuel Cell Science and Technology, vol. 7, 2010, p. 041006.

[24] A.J. del Real, A. Arce, and C. Bordons, "Development and experimental validation of a PEM fuel cell dynamic model," Journal of Power Sources, vol. 173, 2007, pp. 310-324.

[25] V. Vishnyakov, "Proton exchange membrane fuel cells," Vacuum, vol. 80, 2006, pp. 1053-1065.

[26] C. Wang, M.H. Nehrir, and S.R. Shaw, "Dynamic Models and Model Validation for PEM Fuel Cells Using Electrical Circuits," IEEE Transactions on Energy Conversion, vol. 20, Jun. 2005, pp. 442-451.

[27] D. Candusso, F. Harel, A. De Bernardinis, X. Francois, M.-C. Péra, D. Hissel, P. Schott, G. Coquery, and J.-M. Kauffmann, "Characterisation and modelling of a $5 \mathrm{~kW}$ PEMFC for transportation applications," International Journal of Hydrogen Energy, vol. 31, 2006, pp. 10191030.

[28] G. Fontes, C. Turpin, and S. Astier, "A large signal dynamic circuit model of a $\mathrm{H} 2 / \mathrm{O} 2$ PEM fuel cell: description, parameter identification and exploitation," Proceedings of FDFC 2008, Nancy, France: 2008.

[29] Y. Park and J. Caton, "Development of a PEM stack and performance analysis including the effects of water content in the membrane and cooling method," Journal of Power Sources, vol. 179, 2008, pp. 584591.

[30] P.K. Das, X. Li, and Z.-S. Liu, "Analysis of liquid water transport in cathode catalyst layer of PEM fuel cells," International Journal of Hydrogen Energy, vol. 35, Mar. 2010, pp. 2403-2416.

[31] J.P. Owejan, T.A. Trabold, D.L. Jacobson, D.R. Baker, D.S. Hussey, and M. Arif, "In situ investigation of water transport in an operating PEM fuel cell using neutron radiography: Part 2 - Transient water accumulation in an interdigitated cathode flow field," International Journal of Heat and Mass Transfer, vol. 49, Dec. 2006, pp. 4721-4731.

[32] N. Fouquet, C. Doulet, C. Nouillant, G. Dauphin-Tanguy, and B. OuldBouamama, "Model based PEM fuel cell state-of-health monitoring via ac impedance measurements," Journal of Power Sources, vol. 159, 2006, pp. 905-913.

[33] F. Barbir, PEM fuel cells, Springer, 2005.

[34] A. Hernandez, R. Outbib, and D. Hissel, "Diagnostic d'une pile à combustible PEMFC. Une approche statistique," Journal Européen des Systèmes Automatisés, vol. 42, 2008, pp. 1225-1277.

[35] P. Corbo, F. Migliardini, and O. Veneri, "Performance investigation of $2.4 \mathrm{~kW}$ PEM fuel cell stack in vehicles," International Journal of Hydrogen Energy, vol. 32, Dec. 2007, pp. 4340-4349.

[36] E.A. Muller and A.G. Stefanopoulou, "Analysis, Modeling, and Validation for the Thermal Dynamics of a Polymer Electrolyte Membrane Fuel Cell System," 3rd International Conference on Fuel Cell Science, Engineering and Technology, ASME, 2005, pp. 389-404.

[37] J.P. Owejan, T.A. Trabold, J.J. Gagliardo, D.L. Jacobson, R.N. Carter, D.S. Hussey, and M. Arif, "Voltage instability in a simulated fuel cell stack correlated to cathode water accumulation," Journal of Power Sources, vol. 171, Sep. 2007, pp. 626-633. 
[38] P.A.C. Chang, J. St-Pierre, J. Stumper, and B. Wetton, "Flow distribution in proton exchange membrane fuel cell stacks," Journal of Power Sources, vol. 162, Nov. 2006, pp. 340-355.

[39] S.-D. Yim, B.-J. Kim, Y.-J. Sohn, Y.-G. Yoon, G.-G. Park, W.-Y. Lee, C.-S. Kim, and Y.C. Kim, "The influence of stack clamping pressure on the performance of PEM fuel cell stack," Current Applied Physics, vol. 10, Mar. 2010, p. S59-S61.

[40] M. Gerard, J.-P. Poirot-Crouvezier, D. Hissel, and M.-C. Péra, "Oxygen starvation analysis during air feeding faults in PEMFC," International Journal of Hydrogen Energy, 2010, pp. 1-13.
[41] A. Taniguchi, T. Akita, K. Yasuda, and Y. Miyazaki, "Analysis of electrocatalyst degradation in PEMFC caused by cell reversal during fuel starvation," Journal of Power Sources, vol. 130, 2004, pp. 42-49.

[42] A. Taniguchi, T. Akita, K. Yasuda, and Y. Miyazaki, "Analysis of degradation in PEMFC caused by cell reversal during air starvation," International Journal of Hydrogen Energy, vol. 33, 2008, pp. 2323 2329.

[43] S. Knights, "Aging mechanisms and lifetime of PEFC and DMFC," Journal of Power Sources, vol. 127, Mar. 2004, pp. 127-134. 